\title{
HVMANITAS
}

\section{Notes on a special feature of greek orthoepy: use of a non-nasal consonant for representing the velar nasal}

Autor(es): Head, Brian F.

Publicado por: Imprensa da Universidade de Coimbra

URL

persistente:

URI:http://hdl.handle.net/10316.2/38087

DOI:

DOI:http://dx.doi.org/10.14195/2183-1718_67_4

Accessed : $\quad$ 26-Apr-2023 03:35:52

A navegação consulta e descarregamento dos títulos inseridos nas Bibliotecas Digitais UC Digitalis, UC Pombalina e UC Impactum, pressupõem a aceitação plena e sem reservas dos Termos e Condições de Uso destas Bibliotecas Digitais, disponíveis em https://digitalis.uc.pt/pt-pt/termos.

Conforme exposto nos referidos Termos e Condições de Uso, o descarregamento de títulos de acesso restrito requer uma licença válida de autorização devendo o utilizador aceder ao(s) documento(s) a partir de um endereço de IP da instituição detentora da supramencionada licença.

Ao utilizador é apenas permitido o descarregamento para uso pessoal, pelo que o emprego do(s) título(s) descarregado(s) para outro fim, designadamente comercial, carece de autorização do respetivo autor ou editor da obra.

Na medida em que todas as obras da UC Digitalis se encontram protegidas pelo Código do Direito de Autor e Direitos Conexos e demais legislação aplicável, toda a cópia, parcial ou total, deste documento, nos casos em que é legalmente admitida, deverá conter ou fazer-se acompanhar por este aviso.

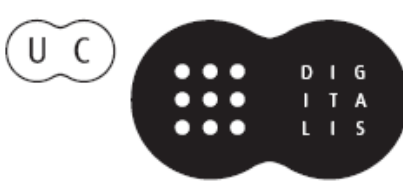


humanitas

\section{Vol. LXVII \\ 2015}

IMPRENSA DA UNIVERSIDADE DE COIMBRA

COIMBRA UNIVERSITY PRESS 


\title{
Notes on a Special Feature of Greek Orthoepy: Use of a Non-Nasal Consonant for RePresenting THE VELAR NASAL
}

\author{
Brian F. Head \\ Emeritus professor, University of Albany \\ bfh122333@gmail.com
}

In memoriam

Américo da Costa Ramalho

\section{Resumo}

O presente estudo descreve os contextos em que se emprega a letra $\gamma$ como representação da consoante nasal velar [ $\mathrm{\eta}]$, apresenta uma hipótese da origem desta consoante e considera um problema que resulta de falhas na representação de étimos gregos em letra latina, com base em dados de vários dicionários de português e de alguns outros idiomas.

Palavras chave: ortoépia, letra gama, nasal velar, étimos gregos, letra romana.

\begin{abstract}
This study describes the contexts in which the letter gama is used in order to represent the velar nasal, it presents a hypothesis as to the origin of this consonant in Greek, and it considers a problem that results from the inadequate representation of Greek etyma in Roman script, as revealed in data from various dictionaries of Portuguese and other languages.
\end{abstract}

Keywords: orthoepy, letter gama, velar nasal, Greek etyma, Roman script. 
In his study on the pronunciation of Greek (Vox Graeca 1987: 35), the classicist Sidney Allen ${ }^{1}$ refers to a special feature of the phonetic values of written forms in Greek: the pronunciation as a velar nasal [ $\mathrm{y}]$ that corresponds to the letter $\gamma$ in sequences of consonants, as in the words ö $\gamma \kappa v \rho \alpha$, है $\gamma \chi 0 \varsigma$,

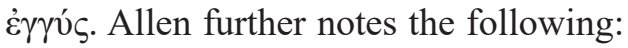

Varro identified this with the sound of $n$ in Latin angulus etc., which is clearly a velar nasal... The use of $n$ to indicate this sound, as in Latin, is understandable enough, since the velar pronunciation is automatic before a velar plosive; and similar spellings with $v$ are found in Attic inscriptions

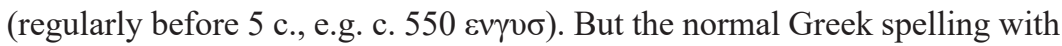
$\gamma$ for $[\mathrm{y}]$ is on the face of it remarkable, since it is as though we were to write e.g. English ink, finger as igk, figger...

In words such as ö $\gamma \gamma \varepsilon \lambda$ os (messenger) "angel”, the letter $\gamma$ is written twice, although this graphic representation is clearly not of a geminate consonant, but rather of a sequence of two phonetically different consonants, of which the first is invariably the velar nasal [ 1 ].

The present study seeks to describe the contexts in which $\gamma$ occurs with the phonetic value of the velar nasal [n], to present a plausible hypothesis with regard to the origin or cause of the phonetic segment and the respective graphic usage, and to call attention to a problem that results from the failure to represent this feature properly.

For an accurate description of the use of the letter $\gamma$ in representing the velar nasal [ $\mathrm{y}]$, it must be noted that the occurrence of $\gamma$ with the phonetic value [y] is not limited to the double $\gamma$ as in the word ó $\gamma \gamma \varepsilon \lambda \mathrm{s}$ (messenger), "angel": this feature of pronunciation also occurs in sequences of $\gamma$ preceding the other letters that represent other velar consonants, namely $\kappa, \chi$ and less frequently $\xi$ (which represents the sequence [ks], of which the first segment is a velar plosive), as in

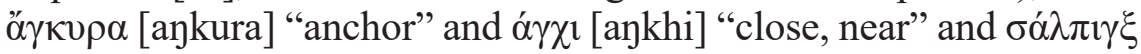

1 Students of Greek can benefit from consulting this work and others by Allen, including Phonetics in Ancient India (Oxford: 1953) and Vox Latina (Oxford: 1978), both of which contain information on the pronunciation of Greek, with the former showing influences of Sanskrit on Greek pronunciation, and the latter features of Latin pronunciation due to influences from Greek. 
[salpinks] "trumpet". Thus, $\gamma \gamma$ represents [ng], while $\gamma \kappa$ represents $[\mathrm{nk}], \gamma \chi$ represents [nkh], and $\gamma \xi$ represents [nks]. ${ }^{2}$

There are numerous additional examples of $\gamma$ for $[\mathfrak{y}$, such as $\alpha \gamma \gamma \alpha \rho \varepsilon i ́ \alpha$

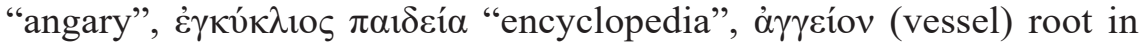
"angiogram" and $\dot{\alpha} \gamma \kappa \omega \dot{v}$ (elbow) "ancona", among others. Some of these words are derived from the ancient Indo-European root *ank- and its variant *ang-, with meanings allied to the notion "bend": from this root, cognates of Greek ö $\gamma \kappa \nu \rho \alpha$ and Latin ancora, of Latin angulus "angle, corner", of

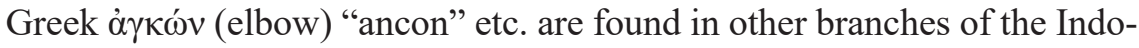
-European family, in addition to Hellenic (represented by Greek) and Italic (represented by Latin), such as Old English anclēow and Old Norse *ankula "ankle", both from Germanic *ankulaz. The Latin word uncus "hooked, bent" and Greek ơ $\gamma \chi 1 \sigma \tau \rho o v$ "hook" are also from this Indo-European root, as are many other words throughout the various branches of Indo-European.

There is also the occurrence of $\gamma \chi$ representing $[\mathrm{gg}]$ in the Greek word $\check{\varepsilon} \gamma \chi \varepsilon \lambda \circ \varsigma$ "eel", which, via Latin anguilla, is the etymon of Spanish enguila, Portuguese enguia, and French anguille, with the second part of the Greek etymon based on the Indo-European root *el- "eel, worm, snakelike creature," as is the Latin form illa in the word anguilla.

The use of double $\gamma \gamma$ with the first $\gamma$ corresponding to the velar nasal [y], also occurs in modern Greek, with ó $\gamma \gamma$ at the beginning of the word for "English" and in related words.

This feature is special partly because it is a non-nasal consonant that is used to indicate the velar nasal. By itself the letter $\gamma$ indicates a voiced velar stop: for it to indicate the velar nasal, it must be followed by a velar consonant that is also non-nasal. Hence, this is clearly not a case of phonetic assimilation, since there is no nasality in the context in which the letter indicating the velar nasal occurs.

The feature in question is special also in the sense that it pertains exclusively to Hellenic branch of the Indo-European family, as represented by Greek, without the occurrence of any comparable feature to be found

2 Although Allen describes the letter $\xi$ as representing the sequence [ks] (ibidem 59), he does not explicitly include that letter along with $\kappa, \chi$ and $\gamma$ in the group of consonants before which $\gamma$ represents [ $\mathrm{\eta}$ ] (ibidem 35), in spite of the fact that the first segment of the group of consonants represented by the letter $\xi$, namely [ks], is a velar plosive. Freire (1974: 13) includes $\xi$ along with $\gamma, \kappa$ and $\chi$, in the group before which $\gamma$ corresponds to a nasal consonant, but the indication of the pronunciation of his example, $\sigma \alpha \dot{\lambda} \pi \tau \gamma \xi$, is inaccurate, since he shows sálpines instead of [salpinks]. 
in the writing system of any of the languages of the other branches of that family.

From the perspectives of students of the classical languages, this feature of Greek is not a mere question of orthography, or how to represent a certain sound in writing. Instead, it is a question of the pronunciation that corresponds to a certain letter in specific contexts (namely, $\gamma$ in sequence with itself or with another velar plosive). Hence, this is not a question merely of orthography, but rather of orthoepy -- the correct pronunciation that corresponds to something that is represented in writing, namely the sequence of $\gamma$ and a letter representing any of the velar plosives.

As for origin, it is important to consider the fact that new features in a language generally come from either of two sources: borrowings from other languages and structural conditioning. In this case, borrowing from another language is not plausible, since the feature is not to be found in any of the languages with which Greek had contact. With regard to the types of structural conditioning, one can consider two domains: paradigmatic and syntagmatic. In this case, paradigmatic seems more relevant, and that is the one considered here.

In the manual by Freire (1974: 16), a chart of Greek consonants is presented, arranged according to the letters employed to represent the various phonetic segments, as defined by their respective features of articulation. This chart is provided below, in an adapted form, with use of appropriate phonetic terminology in English.

\begin{tabular}{llcccc} 
& & \multicolumn{3}{c}{ oral } & nasal \\
occlusive & voiced & voiceless & aspirated & \\
& labial & $\beta$ & $\pi$ & $\varphi$ & $\mu$ \\
& dental & $\delta$ & $\tau$ & $\theta$ & v \\
& velar & $\gamma$ & $\kappa$ & $\chi$ & $\gamma$ before velar \\
continuant & sibilant & $\zeta$ & $\sigma$ & & \\
& liquid & $\lambda, p$ & & &
\end{tabular}

compound or mixed consonants: $\xi, \psi$

Although the preceding information was evidently presented initially for pedagogical purposes, it can also have explanatory value when viewed as a structural paradigm. The four types of occlusives, or stops, indicated 
in the chart are voiced, voiceless, aspirated and nasal. Each of these four types combines with three positions of articulation from front to back: labial, dental and velar. Without the velar nasal, as found in the graphic sequence $\gamma \gamma$, corresponding to the pronunciation [ng], and other sequences (indicated in the chart as "before velar"), the overall paradigm would be incomplete, for there would be a lacuna in the place for the combination of the velar position with the nasal type of articulation, as is found only in the sequences with " $\gamma$ before velar". In summary, the nature of the structure of the consonantal paradigm strongly favors the presence of the velar nasal [ $\mathrm{y}]$ (indicated by " $\gamma$ before velar" in the chart), in addition to the bilabial nasal [m] (indicated by the Greek letter $\mu$ ) and the dental nasal [n] (indicated by the Greek letter $v){ }^{3}$

The preceding considerations are relevant to understanding the conditions of origin of the phonological feature represented by the velar nasal, but they are not relevant to its representation in writing. The question to be resolved with regard to the representation in writing is the reason for use of $\gamma$ to represent [ $\mathrm{y}$ ] when followed by any letter representing a velar consonant. One can note that the writing system of Greek did not include any diacritic symbol that would serve for this purpose. Thus, there were three options: (1) use of the Greek letter $v$ to indicate the velar nasal before a velar plosive, as is found in Attic inscriptions, and is similar to the use of the letter $n$ before velar plosives in Latin, (2) introduction of a new letter or a diacritic into the writing system for this purpose, or (3) use of a combination of existing letters.

With abandonment of the use of the letter $v$ for the velar nasal, the combination of existing letters seems preferable, in view of the fact that the context in which [y] occurs is (a) limited with regard to its environment and (b) uncommon with regard to its relative frequency. Hence, this option is in the interest of maintaining simplicity in the writing system. It is the one that is found in the writing of Greek, both ancient (classical) and modern. However, there is no clear reason for the use of the letter $\gamma$ before velar plosives for this purpose.

It is to be noted that, in view of the diversity found among references to the Greek etyma that are commonly included in dictionaries for general use, the feature $\gamma \gamma$ and, more comprehensively, the use of the letter $\gamma$ followed

3 This paragraph is an adaptation of the ideas of Martinet (1955: passim, especially 104-107). 
by any letter representing a velar consonant, can constitute an obstacle to correct specification of the features of the respective Greek words - at least for some lexicographers, as indicated below.

One can consider, for example, the diversity in references to the same Greek words in some of the common dictionaries of Portuguese and of a few other languages.

The Grande Dicionário (2004) indicates âncora from Greek ágkyra via Latin ancora and anjo from Greek ággelos messenger via ecclesiastic Latin angelu- "angel".

The dictionary of the Academia das Ciências de Lisboa (2001) indicates the origin of âncora as Latin ancorra, from Greek ö $\gamma \kappa \nu \rho \alpha$, and that of anjo

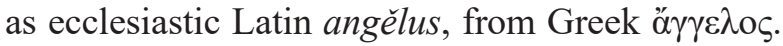

Houaiss (2001) indicates âncora from Latin ancora, borrowing from Greek ágkura.

Michaelis (1998) indicates âncora from Greek ágkyra and anjo from Latin angelu, with no mention of the Greek etymon.

Devoto and Oti (1995) indicate, for Italian, ancora from Latin ancora and angelo from Christian Latin ángelos messenger; from Greek $g k$, $g g$.

Costa e Melo (1994) indicates the origin of anjo as Greek ággelos, via ecclesiastic Latin angélu, and of âncora as Greek ágkyra, via Latin ancora.

For Spanish, the Diccionario da la Real Academia Española (1992) indicates âncora from Latin ancora, and ángel from Latin angelos derived from Greek ö $\gamma \gamma \varepsilon \lambda$ os.

For French, le Grand Robert (1989) indicates, ancre from Latin ancora (with no reference to Greek), ange from Greek aggelos via ecclesiastic Latin angelus.

Ferreira (1986) indicates the origin of âncora as Greek ankyra via Latin ancora, and of anjo as Greek ággelos, via Latin angelu.

Silva (1949-59) indicates the origin of âncora as Greek ágkyra, via Latin ancora, and the origin of anjo as Latin angelus from Greek aggelos.

Figueiredo (1899) indicates the origin of âncora as Latin ancora, from Greek ankura, the origin of anjo as Greek angelos.

Constancio (1844) indicates the origin of ancora as Latin ancora, or the incorrect spelling anchora, from Greek ö $\gamma \kappa \nu \rho \alpha$ ankura, and the origin of anjo as Latin angelus from Greek ö $\gamma \gamma \varepsilon \lambda \mathrm{o}$, , anghelos, "mensageiro, nuncio". In both cases, a broader lexical context for Greek is provided. The letter $h$ occurs after $g$ in anghelos in order to indicate the pronunciation as "hard $g$ ", the velar stop [g]. 
There are numerous differences between the various forms provided for the Greek etyma of âncora and angelus in the dictionaries listed above. The only ones relevant to the objectives of the present study are those related to the representation of the sequences $\gamma \kappa$ and $\gamma \gamma$ of the original Greek words ö $\gamma \kappa v \rho \alpha$ and $\alpha \gamma \gamma \varepsilon \lambda$ os. The following list of the respective representations is included for purposes of comparisons.

$\begin{array}{lcc}\text { Grande dicionário (2004) } & \mathrm{gk} & \mathrm{gg} \\ \text { Houaiss (2001) } & \mathrm{gk} & \mathrm{gg} \\ \text { Ferreira (1999) } & \mathrm{nk} & \mathrm{ng} \\ \text { Michaelis (1998) } & \mathrm{gk} & -- \\ \text { Devoto e Oti (1995) } & \mathrm{nk} & \mathrm{ng} \\ \text { Costa e Melo (1994) } & \mathrm{gk} & \mathrm{gg} \\ \text { Le Grand Robert (1989) } & -- & \mathrm{gg} \\ \text { Silva (1949-59) } & \mathrm{gk} & \mathrm{gg} \\ \text { Figueiredo (1899) } & \mathrm{nk} & \mathrm{ng} \\ \text { Constancio (1844) } & \mathrm{nk} & \mathrm{ngh}\end{array}$

In order to assess the validity of the representation of the Greek etyma in question, one must consider the fact that the Portuguese words âncora and anjo did not come directly from their Greek etyma, but instead via the Latin forms ancora and angelu-. The etyma should be represented in such a way as to reflect clearly the evolution from Greek to Latin. Representation in Roman type of the sequences of $\gamma$ followed by a velar plosive, in the respective Greek etyma as - $g k$ - and - $g g$-, is likely to be misleading with regard to the historical data. As pointed out earlier, these sequences correspond phonetically to [yk] and [yg].

The changes from Greek ö $\gamma \kappa v \rho \alpha$ and ö $\gamma \gamma \varepsilon \lambda$ os to Latin ancŏra and angělus, hence from the sequences $\gamma \kappa[\mathrm{yk}]$ and $\gamma \gamma[\mathrm{gg}]$ in Greek to Latin $n c[\mathrm{yk}]$ and $n g[\mathrm{gg}]$ are both plausible and factual. Changes from Greek $g k$ and $g g$ in Roman print are both implausible and contrary to the historical facts. The dictionaries which indicate $g k$ and $g g$ in Roman print for the sequences $\gamma \kappa[\mathrm{yk}]$ and $\gamma \gamma[\mathrm{yg}]$ in the Greek etyma are likely to give an incorrect notion of the history of the changes from Greek to Latin and then to Portuguese, since such representations in Roman script are likely to be interpreted as representations of the pronunciations. Of course, providing the Greek etyma in their original forms in Cyrillic script can avoid this problem, but many who consult the dictionaries are probably not familiar with the Cyrillic alphabet. Moreover, if reference to the 
Greek words is provided in the original Cyrillic, then anyone consulting this information would also need to be familiar with the conventions relating to the use of $\gamma$ with the phonetic value of the velar nasal. It is disturbing to note that of the ten dictionaries listed above, in which the Greek etyma are indicated in Roman type, only four of them employ a form of representation that is not misleading, but instead corresponds to [ $\mathrm{yk}]$ and [yg], namely $n k$ and $n g$.

In closing, perhaps a word of caution is in order, caveat lector: just because the feature of Greek orthoepy dealt with in the present study is "special", one must not think that it is uncommon; on the contrary, numerous examples of the sequences of $\gamma \gamma$ representing [ng], $\gamma \kappa$ representing $[\mathrm{gk}]$ and $\gamma \chi$ representing [ $\mathrm{ykh}]$, in which the initial $\gamma$ of the consonant cluster corresponds to the velar nasal [ $\mathrm{y}]$, are to be found in all major dictionaries of Greek, such as Hederici (1845), which has the advantage of listing both the Greek words and the corresponding Latin words. For example, Hederici lists more than forty words beginning with $\alpha \gamma \gamma \gamma$, more than ninety beginning with ó $\gamma \kappa$ and more than eighty beginning with $\alpha \gamma \chi$; in all of these, the first consonant in the group beginning with $\gamma$ represents the velar nasal [ $\mathrm{y}$ ], and, of course, throughout the lexicon there are numerous other words with these sequences, in which the initial $\gamma$ of the consonant cluster represents the velar nasal [y].

\section{Bibliography}

Academia das Ciência de Lisboa. Dicionário da Lingua Portuguesa Contemporânea. Lisboa: Academia das Ciências de Lisboa e Editorial Verbo, 2001.

American Heritage Dictionary of Indo-European Roots. Revised and edited by Calvert Watkins. Third edition. Boston \& New York: Houghton, Mifflin, Harcoourt, 2011.

Allen, W. Sidney. Vox Graeca. A guide to the pronunciation of classical Greek. $3^{\text {rd }}$ ed., Oxford: University Press, 1987.

Allen, W. Sidney. Vox Latina. A guide to the pronunciation of classical Latin. $2^{\text {nd }}$ ed., Oxford: University Press, 1978.

Allen, W. Sidney. Phonetics in Ancient India. London Oriental Series, volume I. Oxford: University Press, 1953. 
Constancio, Francisco Solano. Novo diccionario critico e etymologico da lingua portugueza, comprehendo... Paris: Angelo Francisco Carneiro, eidtor proprietário, 1844.

Costa, J. Almeida e A. Sampaio Melo. Dicionário da língua portuguesa. $\sigma^{a}$ edição revista e ampliada. Porto: Porto Editora, 1994.

Devoto, Giacomo e Gian Carlo Oli. II dizionario della lingua italiana. Firenze: Casa Editrice Felice Le Monnier, 1995

Diccionario de la Lengua Española. 21ª edición. Madrid: Real Academia Espanola, 1992.

Ernout, Alfred et Antione Meillet. Dictionnaire étymologique de la langue français. Histoire des mots. Retirage de la 4ème édition augmentée d'additions et de corrections par Jacques André. Paris: Kliencksieck, 2001.

Freire, António. Gramática grega. Oitava edição. Braga: Livraria Apostolado da Imprensa e Publicações da Faculdade de Filosofia, 1987.

Grand Robert de la langue française. Dictionnaire alphabétique er analogique de la langue française de Paul Robert. Deuxième édition entièrement revue et enrichie par Alain Rey. 12 v. Montréal: Les Dictionnaires ROBERT, 1989.

Grande Dicionário da Língua Portuguesa. Porto: Porto Editora, 2004.

Hederici, Benjamini. Lexicon graeco-latinum manuale,... Conimbricae: Typis Academicis, MDCCCXLV.

Houaiss, António e Mauro de A. Salles Villar. Dicionário Houaiss da língua portuguesa. Rio de Janeiro: Objetiva, 2001.

Martinet, André. Économie des changements phonétiques. Traité de phonologie diachronique. Bibliotheca Romanica, Manualia et Commentationes, t. X. Berne: A. Francke, 1955.

Michaelis: moderno dicionário da língua portuguesa. São Paulo: Companhia Melhoramentos, 1998. 